\title{
Delinquent Development, Employment and Income in a Sample of Dutch Organized Crime Offenders: Shape, Content, and Correlates of Delinquent Trajectories from Age 12 to 65
}

\author{
Victor van der Geest, M. Vere van Koppen, and Edward R. Kleemans
}

\section{Introduction}

This chapter describes the shape and content of criminal careers of a large sample of Dutch organized crime offenders and relates these criminal careers to social economic factors such as employment and income. Other chapters in this volume provide systematic reviews of the literature regarding criminal careers of specific-largely understudied - groups, such as criminal careers of organized crime offenders (e.g. Savona et al. 2020). Reviews of the literature demonstrate that the vast majority of studies focuses on juveniles, adolescents, and high-volume crime. Therefore, we do not know whether or not 'established facts' about traditional criminal careers (e.g. Farrington 2003; Blokland and Van der Geest 2017) also hold for criminal careers in organized crime. Does a long and serious criminal career, for example, require an early onset of offending, as is the case for traditional forms of crime? And is employment an important preventive factor for involvement in crime, as is demonstrated by studies on employment and criminal careers (e.g. Van der Geest 2011)? Since organized crime is in many ways different from traditional forms of crime (see below), it is important to focus more empirical research effort on this specific - seriously understudied - group of offenders.

This chapter is based on information from five data sweeps of the Dutch Organized Crime Monitor (OCM) including 1921 offenders, combined with information from the Dutch Offender Index (OBJD) on criminal careers of these offenders and information from Statistics Netherlands (CBS) on education, employment and income of these offenders. After a brief overview of earlier research findings, based on the Dutch Organized Crime Monitor, the methods section presents a description of the data and the analyses (fixed effects and group-based trajectory

V. van der Geest $(\bowtie) \cdot$ M. V. van Koppen · E. R. Kleemans

Department of Criminal Law and Criminology, Faculty of Law, Vrije Universiteit

Amsterdam, Amsterdam, The Netherlands

e-mail: v.vander.geest@vu.nl 
models). In the results section, we describe the criminal careers and employment of those involved in organized crime at a particular moment in their lives. First, the total sample is described in terms of offending, educational background, employment, and legal income. We do not only describe the criminal and employment pathways, but also examine the effect of employment on crime. Second, we divide the total sample in three different ways, allowing comparisons between different subgroups of offenders. The first way is to compare criminal careers and employment for offenders involved in different types of organized crime activities. The second way relates to offenders fulfilling different roles in a criminal organization, whereas the third way distinguishes offenders based on their criminal trajectory. The chapter ends with a conclusion and discussion.

\section{Earlier Findings From the Dutch Organized Crime Monitor}

The Dutch Organized Crime Monitor is an ongoing research project, carried out by the Research and Documentation Centre, VU University Amsterdam, and Erasmus University Rotterdam, focusing on the nature of organized crime in the Netherlands. The main sources for the Dutch Organized Crime Monitor are closed police files of criminal groups, often spanning a period of several years (for more information, see Kleemans 2014). During the period 1996-2017, five data sweeps were carried out, resulting in the systematic analysis of large-scale investigations of 180 criminal groups involved in organized crime. In the Dutch Organized Crime Monitor, organized crime is mainly distinguished from terrorism, corporate crime, group crime, and other types of crime by specific characteristics of the groups involved. Following the definition of the Fijnaut Research group (Fijnaut et al. 1998), criminal groups are considered to be organized crime groups when they are focused primarily on obtaining illegal profits; systematically commit crimes with serious damage to society, and are reasonably capable of shielding their criminal activities from the authorities. Shielding illegal activities from the authorities is possible through various strategies, for example: corruption, violence, intimidation, store fronts, coded communication, counter-surveillance, media manipulation, and the use of experts, such as notaries public, lawyers, and accountants. As police priorities influence to a large extent which criminal groups are investigated in the first place (and to which extent), a random sample of organized crime cases is inconceivable. Therefore, the OCM aims at a wide cross-section of empirical cases, using a strategic selection of cases from a total population of all closed criminal investigations of national and regional investigation teams (including the fiscal police). The 180 large-scale investigations relate to eight different types of organized crime: (1) traditional drugs (cocaine, heroin, cannabis) (2) synthetic drugs, (3) traditional and synthetic drugs, (4) human smuggling, (5) human trafficking, (6) fraud and money laundering, (7) cybercrime, and (8) other types of organized crime activities.

Furthermore, it important to note that many forms of organized crime in the Netherlands can be characterized as 'transit crime' (Kleemans 2007): international 
smuggling activities, such as drug trafficking, smuggling illegal immigrants, human trafficking for sexual exploitation, money laundering and evasion of taxes (cigarette smuggling, European Community Fraud, VAT fraud, for example), whereby the Netherlands can be a production country, transit country, or country of destination. Such activities pose different requirements for offenders than traditional highvolume crime (Kleemans and De Poot 2008). The first distinct feature of these forms of organized crime is the greater importance of social relations, as international trade requires access to suppliers, clients, co-offenders, and profitable criminal opportunities. An important insight from earlier research on the OCM is that not every offender has this access and that building up these relationships (including trust) takes time and energy. The second distinct feature relates to the transnational character of these activities. Given that most existing social networks are often socially and geographically clustered, the trust problem in illicit trade (e.g. Reuter 1983 ) is even more complex and many offenders lack the necessary international contacts that may connect them to these illegal opportunities. Finally, these activities are also logistically far more complex, e.g. transporting illegal goods over long distances and crossing many borders without being noticed by the authorities. Therefore, more co-offenders and specific expertise are often needed, including contacts with the licit world, e.g. for transport, money transactions, and shielding activities from the authorities. Many people lack these contacts and expertise, and some acquire them only later on in life, e.g. though their professional activities and contacts.

In their analysis of 979 suspects who were involved in 79 different organized crime cases of the OCM, Kleemans and De Poot (2008) coined the theoretical concept 'social opportunity structure' - social ties providing access to profitable criminal opportunities - to explain involvement in organized crime. This concept explains why some offenders 'progress' to certain types of organized crime (whereas others do not) and why some people become involved in organized crime only later in life. The study particularly highlighted the significant group of 'late starters', people without any appreciable criminal history, and people in conventional jobs who switch careers.

Furthermore, they analyzed the careers of 66 (ring)leaders and 'nodal' offenders in more detail to find out how their criminal careers had developed. Some (ring)leaders had a long criminal career that could be characterized in four different ways: (1) the versatile but regionally constrained 'local hero' (versatility as a result of both opportunities and constraints of the local context); (2) the offenders who progressed into organized crime through an increase in scale (specialization, particularly in international drug trafficking); (3) those who progressed into organized crime through capital accumulation (investing in drug transports (while refraining from hands-on activities) and becoming a 'background operator'); and (4) those with specific expertise, contacts, and network formation (people getting a central position in criminal networks, because many offenders and criminal groups need their contacts and expertise). Surprisingly, however, a significant share of (ring)leaders could be typified as 'late onset' offenders, who had made a switch from a legal occupational background to organized crime. Among these 32 offenders, a distinction could be 
made between a group of 19 with a background in legal trade (including import and export) and a group of 13 with other types of occupation - people from the business sector, the construction industry, assembly, hotels and catering, financial services or government. Three different types of 'late onset' were described: criminal activities extending from legal activities (opportunities that arise during day-to-day work, particularly in fraud cases); people who obviously switch careers, from legal to illegal commodities, motivated by the huge profits that can be obtained through the trade in prohibited commodities, such as narcotics; and finally, people seizing upon criminal opportunities only later on in life after specific, significant life events (including financial setbacks and problematic debt situations).

Finally, they analyzed criminal careers of 92 'starters', suspects who did not have any other prior judicial contacts and who had not 'progressed' from high-volume crime into organized crime. Five 'involvement mechanisms' were described in more detail: (1) deliberate recruitment by criminal groups, (2) social ties and the social snowball effect, (3) work ties, (4) leisure activities and sidelines, and (5) life events (including financial setbacks).

A follow-up study by Van Koppen et al. (2010b), on a larger dataset, investigated the phenomenon of 'late starters' in more detail. They elaborated upon this research and investigated criminal trajectories of 854 suspects, based upon quantitative and qualitative data from the Dutch Organized Crime Monitor. A semiparametric groupmodel was used to cluster 854 individuals into groups with similar developmental trajectories. The most important finding of this study relates to the substantial group of adult-onset offenders (40\%) and a group without any previous criminal records (19\%), next to a group of early starters (11 percent) and a group of persisters (30\%). Up till then, no trajectory study had ever discovered such a vast share of adult-onset offenders. Furthermore, the findings turn out to be quite robust across different kinds of criminal activities (drugs, fraud, and other criminal activities) and different roles in criminal groups (leaders, coordinators, and lower-level suspects). Adultonset offenders emerge in several kinds of criminal activities and in several kinds of roles in criminal groups.

Differences between the organized crime population and the general offender population were investigated by Van Koppen et al. (2010a). Following up on the finding that many organized crime offenders do not have judicial contacts before adulthood, a surprising result of the comparison was that this also turned out to be the case for the general offender population. However, organized crime offenders do more often have previous judicial contacts, and those previous contacts are also far more serious. Finally, these general findings turn out to be robust, as they also apply when comparisons are made between subsets of the organized crime offenders and the general offender population, for respectively drug crimes and fraud cases.

Van Koppen (2013) studied involvement mechanisms for organized crime in more depth through an analysis of 15 crime groups of the Dutch Organized Crime Monitor, including over 300 offenders. The study shows that the most common involvement in organized crime is through family and friends who are already involved. Almost all offender groups in the analysis contain multiple family ties between offenders, ensuring a basis of trust. Next to family ties, the analyzed groups 
also include individuals from outside the family who bring additional knowledge and contacts. Two types of resources are explicitly discussed. On the one hand, criminally experienced individuals who bring their criminal contacts and are used to the level of excitement. On the other hand, offenders with conventional experience who bring knowledge, skills and privileges gained in their occupational life. Finally, the study highlights involvement related to negative life events: some individuals get involved in organized crime after a financial setback or a relational crisis.

Although employment and work are often seen as preventive factors for involvement in traditional crime, the possible positive effect of employment and work relationships on involvement in organized crime is explicated in a study by Kleemans and Van de Bunt (2008). The analysis is based upon data from 120 case studies of the Dutch Organized Crime Monitor, involving 1623 suspects. The study describes the different kinds of occupations encountered in cases of organized crime and the main characteristics of these occupations. The study concludes that occupations, work relations and work settings may provide the breeding ground for organized crime activities, particularly transit crime. Three different ways in which occupations may present opportunities for committing organized crime are discussed. First, through international contacts and travel movements. This could explain the connection with occupations involving mobility, transport, and logistics: contacts with other countries and other social groups provide ample opportunity to discover and act upon certain opportunities of transit crime. Second, the individual freedom of movement and/or discretion is important. This explains the involvement of directors of (small) businesses, independent professionals and, in some cases, individuals with relative autonomy in larger organizations, such as companies and banks. More trust and autonomy also provide more opportunity of abuse. Third, the social nature of certain occupations is important. Occupations in which people often meet with different people also present many opportunities to meet potential co-offenders, buyers, or suppliers. Furthermore, the study describes various cases in more detail, highlighting the embeddedness of certain organized crime activities in work relations and work settings. A good example is provided by work settings related to ports, such as airport and harbors, which a very important for the import, transit, and exports of illicit goods and/or people. In this volume, Madarie and Kruisbergen provide an in-depth analysis of the importance of such work settings, based on selected cases of the Dutch Organized Crime Monitor.

\section{Methods}

For the purpose of this study, information from the Dutch Organized Crime Monitor (OCM) is combined with information on criminal careers from the Dutch Offender Index (OBJD) and information on education, employment and income, property values and debts from Statistics Netherlands (CBS). 


\section{Data}

\section{Organized Crime Monitor}

In five sweeps of the OCM, information of a wide cross-section of 180 cases concerning various forms of organized crime was collected. In the studied criminal groups, 2305 offenders were involved. Police files and extensive case descriptions allowed for classifying different roles that offenders fulfill and different types of organized crime activities. For the current study, we distinguished three different roles: (1) leaders, (2) coordinators, and (3) offenders with different roles. ${ }^{1}$ Leaders are those offenders who fulfill an executive function in a criminal group; they give orders to co-offenders and monitor the whole criminal process. Coordinators plan and manage concrete criminal activities. For instance, they take care of offenders performing concrete acts, such as transports of drugs. Other offenders are, for example, deployed in the actual transport of illegal goods or act as a facilitator and are responsible for particular logistical processes. Furthermore, based on the primary criterion offence, we distinguished between eight different types of organized crime: (1) traditional drugs, (2) synthetic drugs, (3) traditional and synthetic drugs, (4) human smuggling, (5) human trafficking, (6) fraud and money laundering, (7) cybercrime, and (8) other types of organized crime activities. To make comparisons less complex, we combined the first three categories into one broader category (drugs). Also, since only $1 \%$ of the sample was involved in cybercrime-activities, this category was merged with the other-category. In sum, all individuals are classified as having one of three roles and being involved in one of six types of organized crime activities.

\section{Dutch Offender Index}

For information on offending over the life course, we used information (rap sheets) from the Dutch Offender Index (OBJD). We were able to reconstruct the entire criminal careers for 1921 individuals (out of 2305). These individuals constitute the final sample for this study. For each individual in the sample, information on all judicial contacts registered at the Dutch Public Prosecutor's Office is available from age 12 (the minimum age of legal responsibility in the Netherlands) up to 2016 or death (if this occurred prior to 2016). This not only includes the timing and nature of offenses, but also details of the individual and how the criminal case was adjudicated. Two measures of seriousness were used in the current study. First, the statutory maximum punishment under Dutch law was used, distinguished in three different categories: (1) minor; for offences up to 4 years punishment threat, (2)

\footnotetext{
${ }^{1}$ The role of 64 individuals (3,3\% of the final sample) is unknown. These individuals are, therefore, excluded from the analyses where individuals are distinguished based on their role in a criminal organization.
} 
moderate; for offences with a 4 to 8 years punishment threat, and (3) serious; for offences related to more than 8 years punishment. This measure is independent of the judicial history and circumstances of the suspect, but also does not take into account the conditions under which the offences took place. Therefore, we used a second measure of offence seriousness: the judicial settlement of cases. For each case, it was indicated whether or not an unconditional prison sentence was imposed and what the duration of this prison sentence was. Although this measure is not a pure reflection of the seriousness of the offence (individual circumstances and prior judicial contacts can affect the sentence), it does take into account the conditions under which the offence took place.

\section{Statistics Netherlands}

For all 1921 individuals in the final sample, information on their highest education, employment, income, property values, and debts was collected from Statistics Netherlands. For individuals in the sample, their highest level of education attained was measured in 2015. Unfortunately, information on education is missing for half of the sample. Information on employment, income, property values and debts was available for the entire sample and measured longitudinally from 1999 to 2016, which means that it covers 18 years of each individual's life. For privacy reasons, frequencies lower than ten are not reported.

During the 18-year period, all employment transitions were given (dates of starting a new contract and dates of ending a contract). We used several measures to summarize employment data. First, the distribution of working careers was given by indicating the total amount of time someone was employed during the observation period (never, up to half a year, half a year up to 3 years, 3-7 years, or more than 7 years). Second, $\lambda$ describes the mean number of employed days in a year during the observation period. For example, if individual A works fulltime (365 days) for 5 years and then becomes unemployed for 5 years, his $\lambda$ for this 10 -year period will be 182,5. Third, for each individual, it was determined whether or not he or she was ever self-employed during the observation period. Fourth, we used a longitudinal dichotomous variable to indicate whether an individual was employed or unemployed during a year. An individual is considered employed in a particular year if he or she was employed for at least 182,5 days during that year. This dichotomous employment variable was used in all analyses examining the effect of employment on crime.

Similar to employment, information on income is available longitudinally for year 1999 up to year 2016. Several measures were used to examine legal earnings. First, for each calendar year, total legal income is given in euros. Second, the income percentile compared to the total Dutch population is given for each observed year. Third, the proportion of years with a positive income within the observation period is measured. Finally, it is indicated for each individual whether he or she ever received social benefits during the observation period. It is important to note that by using official register data, the analyses pertain to legal income. Although previous 
studies suggest that undeclared work is often conducted on a self-employed basis, it is unknown to what extent self-employed activities are evidence for undeclared income. Therefore, the analyses of (signals of) illegal income is beyond the scope of the current chapter.

Several measures are used to indicate individuals' properties and debts. First, it was known for each year (1999-2016) what the value of the main property was. Furthermore, the total property value gives the total value of the real estate possessed by an individual. On the other hand, most individuals also have debts. These debts are broken down into mortgage debt and other debts.

\section{Analyses}

Simple comparisons between subgroups of organized crime offenders were carried out. Within tables, differences between subgroups were analyzed by ANOVA's (for continuous variables) or Chi-square tests (for dichotomous variables). In case of a significant difference between multiple subgroups on a continuous variable, Bonferroni post hoc tests were conducted to indicate which subgroups differ significantly.

\section{Fixed Effects Models}

To examine the causal effect of employment on crime, a methodological approach should be used that rules out selection because obtaining a job or becoming unemployed does not occur at random. Employed individuals differ from individuals without a job. A randomized experiment is the best approach to demonstrate a causal effect, but is unrealistic in the current study. One of the next-best approaches to control for a selection bias and demonstrate a causal effect is estimating a fixed effects panel model. A fixed effect model is able to control for unobserved differences between individuals by only measuring within-individual change over time. Because fixed effects models control for all time-stable differences, there is no need to include time-stable control variables. For the total sample as well as for all subgroups based on role, organized crime type and offending pattern, a separate fixed effect model was estimated, indicating the effect of employment on crime for each subgroup.

\section{Group-based Trajectory Models}

Semi-parametric group-modeling was used to cluster groups of individuals with a similar offending pattern over age (Nagin 2005; Nagin et al. 1995). Multiple trajectory analyses were carried out and both the Bayesian Information Criterion and probabilities of group membership were used as a basis for selecting the optimal 
model. Given the chosen model, individuals were assigned to the trajectory where his or her posterior probability of group membership is highest. The trajectory group an offender is assigned to, gives an estimation of the offending path he or she has followed.

\section{Results}

\section{Characteristics of the Offender Sample}

Most individuals in the sample are male (91\%) and a majority was born in the Netherlands (61\%, see Table 1). Five percent died before 2016, which is the end of the observation period, at a mean age of 58 years.

\section{Offending Over the Life Course}

On average, organized crime offenders were 27 years old when their first judicial contact took place (Table 2). On average they committed a total of 11 crimes during their life course. For $9 \%$ of the offenders, the organized crime case is the only crime that was registered. About one-third committed two to five crimes, about one quarter committed up to 10 crimes, and about one-third committed more than 10 crimes during their lives. Most of these crimes are minor, ${ }^{2}$ and on average organized crime offenders committed only one serious crime. Three out of four offenders spent some time in prison during their criminal life-course. On average, they received three separate prison sentences, and spent 2 years in prison. At the time of their organized crime case, they were on average 38 years old. More than one-third was imposed a prison sentence for their organized crime activities, and they spent an average of 10 months in prison. Offending within the sample started rising from age 12 on, reached its peak at the relatively high age of 30, and slowly declined from that age on (Fig. 1). Compared to the traditional age-crime curve (Gottfredson and Hirschi 1990), offending stayed relatively high and only started dropping to a lower level from age 50 onwards.

\section{Life-course Outcomes: Education, Employment and Income}

Table 2 shows life-course outcomes for the organized crime offenders. More than half of the sample with a known educational level, only got elementary or prevocational education. One out of ten received higher education. About a quarter of the

\footnotetext{
${ }^{2}$ However, organized crime offenders were found to commit less minor and considerately more serious offences than the general offender population (Van Koppen et al., 2010a).
} 
Table 1 Descriptives of the sample $(\mathrm{N}=1921)$

\begin{tabular}{|c|c|}
\hline & Mean (SD) / N (\%) \\
\hline Male & $1738(91 \%)$ \\
\hline Born in The Netherlands & $1166(61 \%)$ \\
\hline Died before end observation period & $96(5 \%)$ \\
\hline Age of death & $58.1(10.3)$ \\
\hline \multicolumn{2}{|l|}{ Country of birth } \\
\hline The Netherlands & $1166(61 \%)$ \\
\hline Surinam & $149(8 \%)$ \\
\hline Turkey & $140(7 \%)$ \\
\hline Morocco & $44(2 \%)$ \\
\hline Former Netherlands Antilles & $39(2 \%)$ \\
\hline Other western countries & $98(5 \%)$ \\
\hline Other non-western countries & $280(15 \%)$ \\
\hline Unknown & $5(0 \%)$ \\
\hline \multicolumn{2}{|l|}{ Total criminal career } \\
\hline Age at first crime & $26.7(10.3)$ \\
\hline Number of crimes & $10.9(11.3)$ \\
\hline Violence & $1.0(1.9)$ \\
\hline Property & $2.2(4.4)$ \\
\hline Drugs & $0.9(1.3)$ \\
\hline Other & $6.8(7.0)$ \\
\hline One-shot offender & $172(9 \%)$ \\
\hline $2-5$ crimes & $593(31 \%)$ \\
\hline $6-10$ crimes & $456(24 \%)$ \\
\hline$>10$ crimes & $692(36 \%)$ \\
\hline Number of minor crimes ( $<4$ years punishment threat) & $6.4(6.7)$ \\
\hline Number of moderate crimes ( $4-8$ years punishment threat) & $3.6(5.6)$ \\
\hline Number of serious crimes ( $>=8$ years punishment threat) & $0.9(1.2)$ \\
\hline At least one prison sentence & $1430(74 \%)$ \\
\hline Number of prison sentences & $2.6(3.7)$ \\
\hline Time spent in prison (years) & $2.3(3.7)$ \\
\hline \multicolumn{2}{|l|}{ Criterion case in organized crime } \\
\hline Age & $38.0(9.8)$ \\
\hline Prison sentence & $705(37 \%)$ \\
\hline Length of prison sentence (years) & $0.8(1.8)$ \\
\hline \multicolumn{2}{|l|}{ Role in criminal organization } \\
\hline Leader & $217(11 \%)$ \\
\hline Coordinator & $67(3 \%)$ \\
\hline Other role & $1573(82 \%)$ \\
\hline Role unknown & $64(3 \%)$ \\
\hline \multicolumn{2}{|l|}{ Type of organized crime ${ }^{a}$} \\
\hline Traditional drugs & $611(32 \%)$ \\
\hline Synthetic drugs & $156(8 \%)$ \\
\hline
\end{tabular}


Table 1 (continued)

\begin{tabular}{l|l}
\hline & Mean (SD) / N (\%) \\
\hline Traditional + synthetic drugs & $386(20 \%)$ \\
\hline Human smuggling & $115(6 \%)$ \\
\hline Human trafficking & $73(4 \%)$ \\
\hline Fraud and money laundering & $389(20 \%)$ \\
\hline Cybercrime & $22(1 \%)$ \\
\hline Other & $169(9 \%)$
\end{tabular}

${ }^{a}$ All individuals are classified as being involved in one type of organized crime based on the primary offence in the criterion case

Table 2 Life outcomes

\begin{tabular}{|c|c|}
\hline & Mean (SD) / N (\%) \\
\hline \multicolumn{2}{|l|}{ Highest educational level } \\
\hline Elementary education & $278(15 \%)$ \\
\hline Prevocational education & $205(11 \%)$ \\
\hline Selective secondary education & $67(4 \%)$ \\
\hline Vocational training & $236(12 \%)$ \\
\hline Higher education & $91(5 \%)$ \\
\hline Unknown & $1044(54 \%)$ \\
\hline \multicolumn{2}{|l|}{ Employed } \\
\hline Never during observation period & $467(24 \%)$ \\
\hline $0-0.5$ year & $168(9 \%)$ \\
\hline $0.5-3.0$ years & $388(20 \%)$ \\
\hline $3.0-7.0$ years & $382(20 \%)$ \\
\hline$>7$ years & $516(27 \%)$ \\
\hline $\begin{array}{l}\lambda \text { (mean number of employed days during the observation } \\
\text { period) }\end{array}$ & $93.4(105.5)$ \\
\hline Ever self-employed during observation period & $536(28 \%)$ \\
\hline Mean income per observed year (in euros) & $18,447(22,417)$ \\
\hline Mean income percentile per observed year & $39.3(23.7)$ \\
\hline Proportion of observed years with positive income & $0.8(0.3)$ \\
\hline Ever received social benefits during observation period & $624(34 \%)$ \\
\hline Main property value & $95,233(227,938)$ \\
\hline Total property value & $224,043(2,067,946)$ \\
\hline Mortgage debt & $199,469(265,435)$ \\
\hline Debts (other than mortgage) & $82,951(1,340,081)$ \\
\hline
\end{tabular}

sample was never legally employed during the observation period. Half of the sample was employed up to 7 years (out of 18 years observation) and only one out of four was employed more than 7 years. During the observation period, organized crime offenders were employed on average 93 days a year (25\% of the year). Given that employment participation of the Dutch population fluctuated between 63.8 and $66.7 \%$ during the same period (1999-2016), employment in the organized crime 


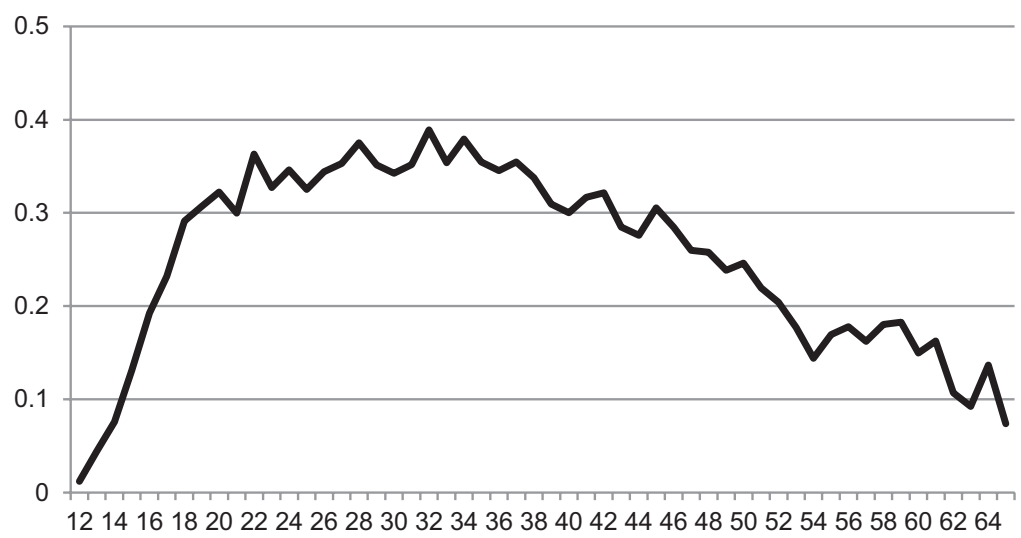

Fig. 1 Offending over the life course

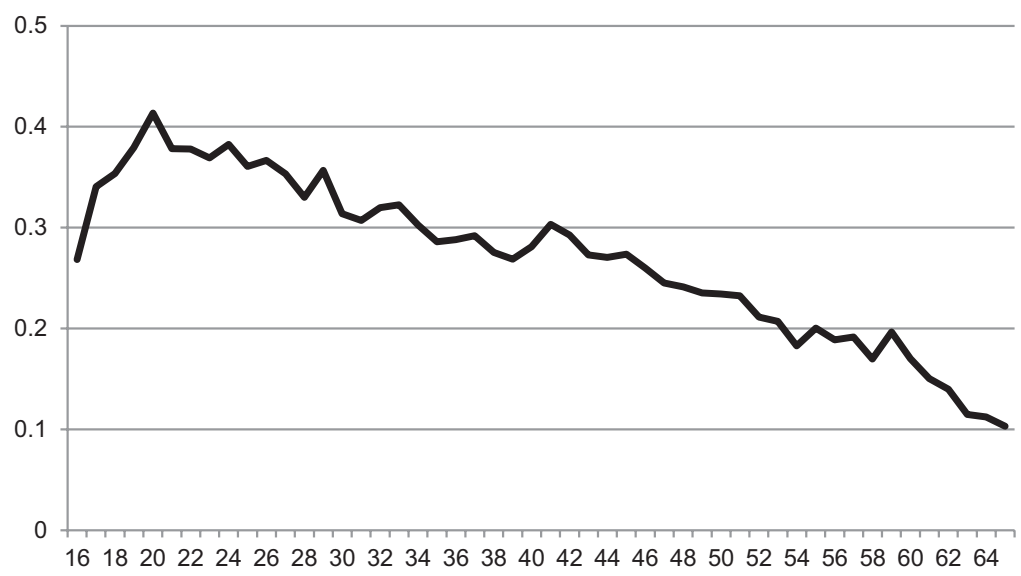

Fig. 2 Employment over the life course

sample can be considered relatively low (Statistics Netherlands 2018). Employment participation is highest in early adulthood, but shows a steady decline from that point on (Fig. 2). Already before the age of retirement, employment dropped to $10 \%$. In the middle of the observation period (2008), employment participation among 15-20 year-olds was 55\%, topped at age 30-35 with 89\%, was still $80 \%$ among 50-55 year-olds and decreased to 33\% among 60-65 year-olds (Statistics Netherlands 2018). More than one out of four organized crime offenders were selfemployed at some time between 1999 and 2016. No effect was found of employment on crime for the total sample (Table 3). The average income in the sample was 18,447 euros, which is at the 39th percentile. One out of three received a social benefit at some point during the observation period. The main property value is relatively low compared to the total property value and the average mortgage debt. 
Table 3 Effect of employment on crime

\begin{tabular}{|c|c|c|}
\hline & $\begin{array}{l}\text { Model } 1 \\
\text { Full sample }\end{array}$ & $\begin{array}{l}\text { Model } 2 \\
\text { Full sample }\end{array}$ \\
\hline & \multicolumn{2}{|l|}{$\mathrm{B}(\mathrm{SD})$} \\
\hline \multicolumn{3}{|l|}{ Control variables } \\
\hline Age & $.13 * * *(.00)$ & $.06 * * *(.01)$ \\
\hline $\mathrm{Age}^{2}$ & $-.00 * * *(.00)$ & $-.00 * * *(.00)$ \\
\hline \multicolumn{3}{|l|}{ Employment } \\
\hline Employed (for at least a half year) & & $.02(.03)$ \\
\hline Log likelihood & $-40,946.20$ & $-16,540.65$ \\
\hline
\end{tabular}

$\dagger \mathrm{p}<0.10, * \mathrm{p}<.05, * * \mathrm{p}<0.01, * * * \mathrm{p}<.001$

\section{Offending and Life Outcomes Distinguished by Role in Criminal Organization}

\section{Descriptives of Role in the Criminal Organization}

Now that the characteristics, offending careers, and life outcomes of the total sample have been examined, we go into more detail and distinguish between several subgroups within the sample. Within criminal groups, offenders can fulfill different roles. One out of 10 offenders acts as a leader of a criminal group, 3\% fulfills a coordinating role, and $82 \%$ has another role within the criminal organization (Table 1). The role of 64 individuals ( $3 \%$ of the sample) is unknown. These individuals are therefore excluded from the analyses where individuals are distinguished based on their role in a criminal organization.

\section{Link Between Employment and Crime: Leaders and Coordinators}

Offenders with a coordinating role differ from leaders and others in most aspects related to their criminal life course. Compared to leaders and those with another role, coordinators are older at the time of their first crime, they commit less crimes (they are more often one-shot offenders and less often chronics [i.e. committing more than 10 crimes]). They also less often receive a prison sentence and spend less time in prison (Table 4). In sum, leaders seem to have more severe criminal careers in terms of frequency and seriousness than coordinators.

In line with these findings on the criminal careers, coordinators have better life outcomes than leaders on many aspects. Coordinators are more often higher educated than leaders and others (Table 5). Only $4 \%$ of the coordinators was never employed during the observation period, compared to $36 \%$ of the leaders and $24 \%$ of the others. Also, $43 \%$ of the coordinators worked for 7 years or more, compared to only $15 \%$ of the leaders and $28 \%$ of the others. On average, coordinators were employed 147 days a year, compared to 55 days (leaders) and 97 days (others). Coordinators also had a higher income and less often received social benefits. 
Table 4 Offending distinguished by role in criminal organization

\begin{tabular}{|c|c|c|c|}
\hline & $\begin{array}{l}\text { Leader } \\
(\mathrm{N}=217)\end{array}$ & $\begin{array}{l}\text { Coordinator } \\
(\mathrm{N}=67)\end{array}$ & $\begin{array}{l}\text { Other role } \\
(\mathrm{N}=1573)\end{array}$ \\
\hline & \multicolumn{3}{|c|}{ Mean (SD) / N (\%) } \\
\hline Age at first crime $* * *$ & $26.7^{\mathrm{A}}(9.2)$ & $31.4^{\mathrm{B}}(12.4)$ & $\begin{array}{l}26.3^{\mathrm{A}} \\
(10.3)\end{array}$ \\
\hline Age at criterion case & $38.4(8.8)$ & $38.4(9.5)$ & $37.9(10.0)$ \\
\hline \multicolumn{4}{|l|}{ Total criminal career } \\
\hline One-shot offender $* *$ & $9(4 \%)$ & $12(18 \%)$ & $139(9 \%)$ \\
\hline $2-5$ crimes $*$ & $61(28 \%)$ & $31(46 \%)$ & $479(31 \%)$ \\
\hline $6-10$ crimes & $49(23 \%)$ & $16(24 \%)$ & $378(24 \%)$ \\
\hline$>10$ crimes $* * *$ & $96(45 \%)$ & $8(12 \%)$ & $571(36 \%)$ \\
\hline Number of crimes**** & $\begin{array}{l}12.0^{\mathrm{A}} \\
(11.5)\end{array}$ & $5.6^{\mathrm{B}}(5.4)$ & $\begin{array}{l}11.1^{\mathrm{A}} \\
(11.5)\end{array}$ \\
\hline Violence* & $1.0^{\mathrm{AB}}(1.8)$ & $0.4^{\mathrm{A}}(1.0)$ & $1.0^{\mathrm{B}}(2.0)$ \\
\hline Property $\dagger$ & $2.6(5.6)$ & $1.2(1.7)$ & $2.3(4.3)$ \\
\hline Drugs $* * *$ & $1.2^{\mathrm{A}}(1.4)$ & $0.5^{\mathrm{B}}(0.7)$ & $0.8^{\mathrm{C}}(1.3)$ \\
\hline Other*** & $7.2^{\mathrm{A}}(6.2)$ & $3.5^{\mathrm{B}}(3.8)$ & $6.9^{\mathrm{A}}(7.1)$ \\
\hline $\begin{array}{l}\text { Number of minor crimes }(<4 \text { years punishment } \\
\text { threat }) * * *\end{array}$ & $6.7^{\mathrm{A}}(6.0)$ & $3.2^{\mathrm{B}}(3.7)$ & $6.5^{\mathrm{A}}(6.8)$ \\
\hline $\begin{array}{l}\text { Number of moderate crimes ( } 4-8 \text { years punishment } \\
\text { threat)** }\end{array}$ & $4.0^{\mathrm{A}}(6.6)$ & $1.6^{\mathrm{B}}(2.4)$ & $3.7^{\mathrm{A}}(5.6)$ \\
\hline $\begin{array}{l}\text { Number of serious crimes }(>=8 \text { years punishment } \\
\text { threat)*** }\end{array}$ & $1.3^{\mathrm{A}}(1.3)$ & $0.8^{\mathrm{B}}(0.8)$ & $0.9^{\mathrm{B}}(1.3)$ \\
\hline At least one prison sentence $* * *$ & $174(80 \%)$ & $37(55 \%)$ & $1178(75 \%)$ \\
\hline Number of prison sentences $* *$ & $3.0^{\mathrm{A}}(3.7)$ & $1.0^{\mathrm{B}}(1.5)$ & $2.6^{\mathrm{A}}(3.8)$ \\
\hline Time spent in prison (years)*** & $4.4^{\mathrm{A}}(5.0)$ & $1.0^{\mathrm{B}}(1.8)$ & $2.1^{\mathrm{B}}(3.5)$ \\
\hline \multicolumn{4}{|l|}{ Organized crime case } \\
\hline Prison sentence $* * *$ & $113(52 \%)$ & $22(33 \%)$ & $570(36 \%)$ \\
\hline Length of prison sentence (years) $* * *$ & $2.2^{\mathrm{A}}(2.9)$ & $0.6^{\mathrm{B}}(1.4)$ & $0.7^{\mathrm{B}}(1.5)$ \\
\hline
\end{tabular}

Significant difference between offenders fulfilling different roles are indicated per variable $(\dagger \mathrm{p}<0.10, * \mathrm{p}<.05, * * \mathrm{p}<0.01, * * * \mathrm{p}<.001)$. Within each row, different superscripts indicate a significant difference between offenders with different roles $(\mathrm{p}<0.05)$. For example, $A$ and $B$ differ significantly; $A B$ differs from neither $A$ nor $B$

Neither significant differences between the subgroups were found in the number of offenders that were self-employed, nor were any differences found in property values and debts between leaders, coordinators, and others.

Interestingly, both leaders and coordinators show a different pattern than is standard in the literature on the relationship between employment and crime: both for leaders and coordinators, a significant positive effect of employment on crime was found (Table 6, Model 3 and 4). Employment significantly increases offending with $31 \%$ for leaders and with $46 \%$ for coordinators. The only group that benefits from employment in the sense that they commit less crimes, are those with other roles; employment accounts for a crime reduction of $7 \%$ for this subgroup (Table 6, Model 5). 
Table 5 Life outcomes distinguished by role in criminal organization ${ }^{\mathrm{a}}$

\begin{tabular}{|c|c|c|c|}
\hline & $\begin{array}{l}\text { Leader } \\
(\mathrm{N}=217)\end{array}$ & $\begin{array}{l}\text { Coordinator } \\
(\mathrm{N}=67)\end{array}$ & $\begin{array}{l}\text { Other role } \\
(\mathrm{N}=1573)\end{array}$ \\
\hline & & \multicolumn{2}{|c|}{ Mean (SD) / N (\%) } \\
\hline \multicolumn{4}{|l|}{ Highest educational level $* * *$} \\
\hline Elementary education & $31(14 \%)$ & $<10$ & $232(15 \%)$ \\
\hline Prevocational education & $16(7 \%)$ & $<10$ & $179(11 \%)$ \\
\hline Selective secondary education & $<10$ & $<10$ & $57(4 \%)$ \\
\hline Vocational training & $14(6 \%)$ & $13(19 \%)$ & $200(13 \%)$ \\
\hline Higher education & $<10$ & $11(16 \%)$ & $70(4 \%)$ \\
\hline Unknown & $143(66 \%)$ & $31(46 \%)$ & $835(53 \%)$ \\
\hline \multicolumn{4}{|l|}{ Employed $* * *$} \\
\hline Never during observation period & $78(36 \%)$ & $3(4 \%)$ & $274(24 \%)$ \\
\hline $0-0.5$ year & $18(8 \%)$ & $3(4 \%$ & $141(9 \%)$ \\
\hline $0.5-3.0$ years & $58(26 \%)$ & $13(19 \%)$ & $298(19 \%)$ \\
\hline $3.0-7.0$ years & $30(14 \%)$ & $19(28 \%)$ & $321(20 \%)$ \\
\hline$>7$ years & $33(15 \%)$ & $29(43 \%)$ & $439(28 \%)$ \\
\hline $\begin{array}{l}\lambda \text { (mean number of employed days during } \\
\text { the observation period) } * * *\end{array}$ & $54.6^{\mathrm{A}}(75.7)$ & $147.2^{\mathrm{B}}(112.6)$ & $96.7^{\mathrm{C}}(107.3)$ \\
\hline $\begin{array}{l}\text { Ever self-employed during observation } \\
\text { period }\end{array}$ & $49(23 \%)$ & $18(27 \%)$ & $449(29 \%)$ \\
\hline $\begin{array}{l}\text { Mean income per observed year (in } \\
\text { euros) } * * *\end{array}$ & $\begin{array}{l}14,098^{\mathrm{A}} \\
(19,156)\end{array}$ & $\begin{array}{l}29,781^{\mathrm{B}} \\
(35,011)\end{array}$ & $\begin{array}{l}18,573^{\mathrm{C}} \\
(22,149)\end{array}$ \\
\hline $\begin{array}{l}\text { Mean income percentile per observed } \\
\text { year*** }\end{array}$ & $18.8^{\mathrm{A}}(20.9)$ & $37.7^{\text {B }}(29.9)$ & $28.7^{\mathrm{C}}(25.3)$ \\
\hline $\begin{array}{l}\text { Proportion of observed years with positive } \\
\text { income } * * *\end{array}$ & $0.6^{\mathrm{A}}(0.4)$ & $0.8^{\mathrm{B}}(0.3)$ & $0.8^{\mathrm{B}}(0.3)$ \\
\hline $\begin{array}{l}\text { Ever received social benefits during } \\
\text { observation period } * *\end{array}$ & $73(37 \%)$ & $10(16 \%)$ & $521(35 \%)$ \\
\hline Main property value & $\begin{array}{l}90,651 \\
(250,493)\end{array}$ & $\begin{array}{l}143,489 \\
(193,774)\end{array}$ & $\begin{array}{l}94,601 \\
(228,528)\end{array}$ \\
\hline Total property value & $\begin{array}{l}192,581 \\
(631,048)\end{array}$ & $\begin{array}{l}217,794 \\
(323,540)\end{array}$ & $\begin{array}{l}232,745 \\
(2,256,016)\end{array}$ \\
\hline Mortgage debt & $\begin{array}{l}200,457 \\
(190,687)\end{array}$ & $\begin{array}{l}254,321 \\
(265,397)\end{array}$ & $\begin{array}{l}196,769 \\
(274,144)\end{array}$ \\
\hline Debts (other than mortgage) & $\begin{array}{l}45,128 \\
(244,843)\end{array}$ & $\begin{array}{l}54,061 \\
(151,413)\end{array}$ & $\begin{array}{l}91,432 \\
(1,466,785)\end{array}$ \\
\hline
\end{tabular}

Significant difference between offenders fulfilling different roles are indicated per variable $(\dagger \mathrm{p}<0.10, * \mathrm{p}<.05, * * \mathrm{p}<0.01, * * * \mathrm{p}<.001)$. Within each row, different superscripts indicate a significant difference between offenders with different roles $(\mathrm{p}<0.05)$. For example, $A$ and $B$ differ significantly; $A B$ differs from neither $A$ nor $B$

${ }^{\text {aF }}$ For privacy reasons, frequencies lower than ten are not reported 
Table 6 Effect of employment on crime differentiated by role in criminal organization

\begin{tabular}{l|l|l|l}
\hline & $\begin{array}{l}\text { Model 3 } \\
\text { Leaders } \\
\text { B (SD) }\end{array}$ & $\begin{array}{l}\text { Model 4 } \\
\text { Coordinators }\end{array}$ & $\begin{array}{l}\text { Model 5 } \\
\text { Other role }\end{array}$ \\
\hline \multicolumn{4}{l}{} \\
\hline Control variables & $-.06 *(.03)$ & $.21 * * *(.06)$ & $.06 * * *(.01)$ \\
\hline Age & $.00(.00)$ & $-.00 * * *(.00)$ & $-.00 * * *(.00)$ \\
\hline Age $^{2}$ & $.27 * *(.10)$ & $.38 *(.18)$ & $-.07 *(.03)$ \\
\hline Employment & -1807.45 & -426.48 & $-13,832.14$ \\
\hline Employed (for at least a half year) &
\end{tabular}

$\dagger \mathrm{p}<0.10, * \mathrm{p}<.05, * * \mathrm{p}<0.01, * * * \mathrm{p}<.001$

\section{Offending and Life Outcomes Distinguished by Type of Organized Crime}

\section{Descriptives of the Type of Organized Crime}

Offenders do not only fulfill different roles within a criminal group, but are also involved in different types of organized crime (Table 1). The majority (60\%) was involved in drug-related activities: traditional drugs (32\%), synthetic drugs $(8 \%)$ or both $(20 \%)$. Smaller numbers were involved in human smuggling $(6 \%)$, human trafficking $(4 \%)$, or cybercrime $(1 \%)$. One out of five was involved in organized fraud. Nine percent of the offenders was involved in other types of organized crime.

\section{Link Between Employment and Crime: Different Types of Organized Crime}

On average, offenders in each subgroup were involved in crime for the first time between age 24 and 30 (Table 7). However, drugs offenders (26 years) and those involved in other activities (24 years), were younger at time of their first offence than those involved in human trafficking (29 years), and fraud (30 years). At the time of the organized crime cases, offenders involved in organized fraud (39 years) were significantly older than those involved in human smuggling (32 years). During their criminal career, offenders involved in organized drug-related (12 crimes) or other activities ( 14 crimes) committed significantly more crimes than those involved in human smuggling (6 crimes), human trafficking (8 crimes), or organized fraud ( 9 crimes). Also, they committed more moderate and serious crimes than those involved in other organized crime activities. Relatedly, offenders involved in drug activities in organized crime, spent more time in prison during their lives than all other groups.

In terms of life outcomes, fraud offenders distinguish themselves from all other organized crime offenders. Compared to offenders in other types of organized crime activities (drugs, human smuggling, human trafficking, other activities), 
Table 7 Offending distinguished by type of organized crime

\begin{tabular}{|c|c|c|c|c|c|}
\hline & $\begin{array}{l}\text { Drugs } \\
(\mathrm{N}=1153)\end{array}$ & $\begin{array}{l}\text { Human } \\
\text { smuggling } \\
(\mathrm{N}=115)\end{array}$ & $\begin{array}{l}\text { Human } \\
\text { trafficking } \\
(\mathrm{N}=73)\end{array}$ & $\begin{array}{l}\text { Fraud } \\
(\mathrm{N}=389)\end{array}$ & $\begin{array}{l}\text { Other } \\
(\mathrm{N}=191)\end{array}$ \\
\hline & \multicolumn{5}{|c|}{ Mean (SD) / N (\%) } \\
\hline Age at first crime $* * *$ & $\begin{array}{l}25.7^{\mathrm{AB}} \\
(9.8)\end{array}$ & $27.7^{\mathrm{AC}}(7.3)$ & $29.1^{\mathrm{C}}(9.8)$ & $\begin{array}{l}29.9^{\mathrm{C}} \\
(11.2)\end{array}$ & $\begin{array}{l}24.3^{\mathrm{B}} \\
(11.1)\end{array}$ \\
\hline Age at criterion case $* * *$ & $\begin{array}{l}38.9^{\mathrm{A}} \\
(10.1)\end{array}$ & $32.2^{\mathrm{B}}(8.9)$ & $\begin{array}{l}35.0^{\mathrm{AB}} \\
(8.5)\end{array}$ & $\begin{array}{l}38.6^{\mathrm{AC}} \\
(8.8)\end{array}$ & $\begin{array}{l}35.5^{\mathrm{BC}} \\
(8.9)\end{array}$ \\
\hline \multicolumn{6}{|l|}{ Total criminal career } \\
\hline One-shot offender $* * *$ & $71(6 \%)$ & $18(16 \%)$ & $15(21 \%)$ & $52(13 \%)$ & $16(8 \%)$ \\
\hline $2-5$ crimes $* * *$ & $315(27 \%)$ & $48(42 \%)$ & $23(32 \%)$ & $\begin{array}{l}157 \\
(40 \%)\end{array}$ & $50(26 \%)$ \\
\hline $6-10$ crimes $\dagger$ & $287(25 \%)$ & $32(28 \%)$ & $20(27 \%)$ & $73(19 \%)$ & $44(23 \%)$ \\
\hline$>10$ crimes $* * *$ & $473(41 \%)$ & $16(14 \%)$ & $15(21 \%)$ & $\begin{array}{l}107 \\
(28 \%)\end{array}$ & $81(42 \%)$ \\
\hline Number of crimes $* * *$ & $\begin{array}{l}11.9^{\mathrm{A}} \\
(11.4) \\
\end{array}$ & $6.0^{\mathrm{B}}(5.6)$ & $7.9^{\mathrm{B}}(8.8)$ & $8.6^{\mathrm{B}}(9.7)$ & $\begin{array}{l}13.8^{\mathrm{A}} \\
(15.1)\end{array}$ \\
\hline Violence $* * *$ & $1.1^{\mathrm{A}}(2.0)$ & $0.3^{\mathrm{B}}(0.7)$ & $\begin{array}{l}1.0 \mathrm{~A}^{\mathrm{BC}} \\
(2.2)\end{array}$ & $0.6^{\mathrm{B}}(1.4)$ & $1.6^{\mathrm{C}}(2.5)$ \\
\hline Property $* * *$ & $2.2^{\mathrm{A}}(3.9)$ & $0.9^{\mathrm{B}}(1.4)$ & $1.4^{\mathrm{AB}}(2.3)$ & $\begin{array}{l}2.0^{\mathrm{AB}} \\
(3.5)\end{array}$ & $4.1^{\mathrm{C}}(8.1)$ \\
\hline Drugs $* * *$ & $1.2^{\mathrm{A}}(1.4)$ & $0.1^{\mathrm{B}}(0.4)$ & $0.1^{\mathrm{BC}}(0.4)$ & $0.4^{\mathrm{BC}}(1.0)$ & $0.6^{\mathrm{C}}(1.2)$ \\
\hline Other $* * *$ & $7.4^{\mathrm{A}}(7.3)$ & $4.7^{\mathrm{B}}(4.8)$ & $5.4^{\mathrm{AB}}(5.6)$ & $5.7^{\mathrm{B}}(6.2)$ & $7.6^{\mathrm{A}}(7.3)$ \\
\hline $\begin{array}{l}\text { Number of minor crimes }(< \\
4 \text { years punishment } \\
\text { threat)*** }\end{array}$ & $7.0^{\mathrm{A}}(7.0)$ & $3.9^{\mathrm{B}}(4.6)$ & $4.5^{\mathrm{BC}}(5.4)$ & $5.3^{\mathrm{BC}}(6.1)$ & $7.0^{\mathrm{AC}}(6.9)$ \\
\hline $\begin{array}{l}\text { Number of moderate crimes } \\
\text { ( } 4-8 \text { years punishment } \\
\text { threat)*** }\end{array}$ & $3.8^{\mathrm{A}}(5.3)$ & $1.8^{\mathrm{B}}(1.8)$ & $2.5^{\mathrm{AB}}(4.0)$ & $2.7^{\mathrm{B}}(4.4)$ & $5.9^{\mathrm{C}}(9.6)$ \\
\hline $\begin{array}{l}\text { Number of serious crimes } \\
(>=8 \text { years punishment } \\
\text { threat)*** }\end{array}$ & $1.1^{\mathrm{A}}(1.3)$ & $0.3^{\mathrm{B}}(0.5)$ & $0.9^{\mathrm{AC}}(1.1)$ & $0.5^{\mathrm{BC}}(1.1)$ & $1.0^{\mathrm{A}}(1.5)$ \\
\hline $\begin{array}{l}\text { At least one prison } \\
\text { sentence } * * *\end{array}$ & $904(78 \%)$ & $94(82 \%)$ & $54(74 \%)$ & $\begin{array}{l}242 \\
(62 \%)\end{array}$ & $\begin{array}{l}136 \\
(71 \%)\end{array}$ \\
\hline $\begin{array}{l}\text { Number of prison } \\
\text { sentences } * * *\end{array}$ & $2.9^{\mathrm{AC}}(3.8)$ & $1.4^{\mathrm{B}}(1.2)$ & $1.8^{\mathrm{AB}}(2.6)$ & $1.7^{\mathrm{B}}(3.1)$ & $3.5^{\mathrm{C}}(5.1)$ \\
\hline $\begin{array}{l}\text { Time spent in prison } \\
\text { (years)*** }\end{array}$ & $2.9^{\mathrm{A}}(4.2)$ & $1.5^{\mathrm{B}}(2.1)$ & $1.7^{\mathrm{B}}(2.8)$ & $1.2^{\mathrm{B}}(2.5)$ & $1.5^{\mathrm{B}}(2.9)$ \\
\hline \multicolumn{6}{|l|}{ Organized crime case } \\
\hline Prison sentence $* * *$ & $465(40 \%)$ & $62(54 \%)$ & $26(36 \%)$ & $91(23 \%)$ & $61(32 \%)$ \\
\hline $\begin{array}{l}\text { Length of prison sentence } \\
\text { (years)*** }\end{array}$ & $1.1^{\mathrm{A}}(2.1)$ & $0.8^{\mathrm{AB}}(1.3)$ & $0.7^{\mathrm{AC}}(1.8)$ & $0.2^{\mathrm{C}}(0.7)$ & $0.4^{\mathrm{BC}}(1.0)$ \\
\hline
\end{tabular}

Significant difference between offenders fulfilling different roles are indicated per variable $(\dagger \mathrm{p}<0.10, * \mathrm{p}<.05, * * \mathrm{p}<0.01, * * * \mathrm{p}<.001)$. Within each row, different superscripts indicate a significant difference between offenders involved in different types of organized crime $(\mathrm{p}<0.05)$. For example, $A$ and $B$ differ significantly; $A B$ differs from neither $A$ nor $B$ 
organized fraud offenders attained a higher educational level, more often were employed and for longer periods of time, had higher incomes, less often received social benefits, and had substantially higher property values (Table 8). Although the absolute value of the debts of organized fraud offenders also is the highest out of the five groups, the difference with debts of the others groups did not reach significance. Also, no effect was found of employment on crime for any of the subgroups (Table 9).

\section{Offending and Life Outcomes Distinguished by Offending Trajectories Over the Life-Course}

\section{Description of Developmental Trajectories and Their Link to Offending Characteristics}

A six-group model was selected as the optimal model to fit the criminal careers of the $1913^{3}$ organized crime offenders (Appendix A). Figure 3 provides a graphical representation of the criminal careers of the six distinguished groups. Offending characteristics of each of the six distinct groups are presented in Table 10. The first three trajectory groups are named after the specific onset ages of the developmental group. Their criminal pathways have similar shapes, but they started and peaked at different stages in life. First, early-onset offenders are, together with high-frequency offenders, the first to have started their criminal career at age 17. Around age 32, they were again one of the youngest trajectory groups at the time of the criterion case in organized crime. Nine out of ten early-onset offenders committed more than 10 crimes and $94 \%$ spent some time in prison during their careers. Mid-onset offenders started offending a couple of years later, but they resemble early-onset offenders in that they relatively often accumulated a large number of crimes $(92 \%$ more than 10 crimes) and also relatively often were convicted to prison at least once (89\%). Late-onset offenders committed their first crime only around age 28 and were halfway their $40 \mathrm{~s}$ at the time of their criterion case in organized crime. Three out of four are chronics ( $>10$ crimes) and, on average, they also committed fewer crimes than those with an early- or mid-onset start in crime. A fourth trajectory group is labelled low-frequency offenders; they were 22 years old when they committed their first crime, and committed fewer crimes in their careers than the first three groups. Only $13 \%$ of the low-frequency offenders committed more than 10 crimes. High-frequency offenders started as early as early-onset offenders, but all committed more than 10 crimes, with an average of 47 crimes. They did not only commit the most minor crimes, but also the most moderate and serious crimes of all trajectory groups. All high-frequency offenders spent some time in prison and, on average, they also spent the most time in prison. Most individuals (33\%) were

\footnotetext{
${ }^{3}$ The original sample contained 1921 offenders, but 8 offenders were excluded due to missing values.
} 
Table 8 Life outcomes distinguished by type of organized crime

\begin{tabular}{|c|c|c|c|c|c|}
\hline & $\begin{array}{l}\text { Drugs } \\
(\mathrm{N}=1153)\end{array}$ & $\begin{array}{l}\text { Human } \\
\text { Smuggling } \\
(\mathrm{N}=115)\end{array}$ & $\begin{array}{l}\text { Human } \\
\text { trafficking } \\
(\mathrm{N}=73)\end{array}$ & $\begin{array}{l}\text { Fraud } \\
(\mathrm{N}=389)\end{array}$ & $\begin{array}{l}\text { Other } \\
(\mathrm{N}=191)\end{array}$ \\
\hline & \multicolumn{5}{|c|}{ Mean (SD)/N (\%) } \\
\hline \multicolumn{6}{|l|}{ Highest educational level** } \\
\hline Elementary education & $176(15 \%)$ & $23(20 \%)$ & $12(16 \%)$ & $37(10 \%)$ & $30(16 \%)$ \\
\hline Prevocational education & $132(11 \%)$ & $12(10 \%)$ & $<10$ & $28(7 \%)$ & $27(14 \%)$ \\
\hline $\begin{array}{l}\text { Selective secondary } \\
\text { education }\end{array}$ & $34(3 \%)$ & $<10$ & $<10$ & $15(4 \%)$ & $<10$ \\
\hline Vocational training & $128(11 \%)$ & $\approx 10$ & $<10$ & $44(11 \%)$ & $45(24 \%)$ \\
\hline Higher education & $39(3 \%)$ & $<10$ & $<10$ & $28(7 \%)$ & $\approx 10$ \\
\hline Unknown & $644(56 \%)$ & $56(49 \%)$ & $42(58 \%)$ & $236(61 \%)$ & $66(35 \%)$ \\
\hline \multicolumn{6}{|l|}{ Employed $\dagger$} \\
\hline $\begin{array}{l}\text { Never during } \\
\text { observation period }\end{array}$ & $303(26 \%)$ & $31(27 \%)$ & $24(33 \%)$ & $73(20 \%)$ & $36(19 \%)$ \\
\hline $0-0.5$ year & $91(8 \%)$ & $10(9 \%)$ & $3(4 \%)$ & $32(8 \%)$ & $32(17 \%)$ \\
\hline $0.5-3.0$ years & $228(20 \%)$ & $27(32 \%)$ & $19(26 \%)$ & $77(20 \%)$ & $37(19 \%)$ \\
\hline $3.0-7.0$ years & $232(20 \%)$ & $16(14 \%)$ & $16(22 \%)$ & $83(21 \%)$ & $35(18 \%)$ \\
\hline$>7$ years & $299(26 \%)$ & $31(27 \%)$ & $11(15 \%)$ & $124(32 \%)$ & $51(27 \%)$ \\
\hline $\begin{array}{l}\lambda \text { (mean number of } \\
\text { employed days during the } \\
\text { observation period) } * *\end{array}$ & $\begin{array}{l}89.6^{\mathrm{A}} \\
(103.3)\end{array}$ & $\begin{array}{l}88.1^{\mathrm{AB}} \\
(108.9)\end{array}$ & $69.3^{\mathrm{A}}(89.1)$ & $\begin{array}{l}111.0^{\mathrm{B}} \\
(112.2)\end{array}$ & $\begin{array}{l}93.0^{\mathrm{AB}} \\
(105.5)\end{array}$ \\
\hline $\begin{array}{l}\text { Ever self-employed } \\
\text { during observation } \\
\text { period } \dagger\end{array}$ & $315(27 \%)$ & $26(23 \%)$ & $15(21 \%)$ & $129(33 \%)$ & $51(27 \%)$ \\
\hline $\begin{array}{l}\text { Mean income per } \\
\text { observed year (in } \\
\text { euros) } * * *\end{array}$ & $\begin{array}{l}16,819^{\mathrm{A}} \\
(18,737)\end{array}$ & $\begin{array}{l}14,824^{\mathrm{A}} \\
(11,854)\end{array}$ & $\begin{array}{l}11,062^{\mathrm{A}} \\
(12,440)\end{array}$ & $\begin{array}{l}25,680^{\mathrm{B}} \\
(32,413)\end{array}$ & $\begin{array}{l}18,085^{\mathrm{A}} \\
(21,920)\end{array}$ \\
\hline $\begin{array}{l}\text { Mean income percentile } \\
\text { per observed year*** }\end{array}$ & $27.1^{\mathrm{A}}(24.0)$ & $\begin{array}{l}24.3^{\mathrm{AB}} \\
(22.8)\end{array}$ & $17.9^{\mathrm{B}}(21.9)$ & $33.0^{\mathrm{C}}(29.3)$ & $\begin{array}{l}28.8^{\mathrm{AC}} \\
(24.7)\end{array}$ \\
\hline $\begin{array}{l}\text { Proportion of observed } \\
\text { years with positive } \\
\text { income } \dagger\end{array}$ & $0.7(0.3)$ & $0.8(0.3)$ & $0.7(0.4)$ & $0.8(0.3)$ & $0.8(0.3)$ \\
\hline $\begin{array}{l}\text { Ever received social } \\
\text { benefits during } \\
\text { observation period } * * *\end{array}$ & $369(34 \%)$ & $55(54 \%)$ & $27(43 \%)$ & $95(26 \%)$ & $78(42 \%)$ \\
\hline Main property value $* * *$ & $\begin{array}{l}78,928^{\mathrm{A}} \\
(174,719)\end{array}$ & $\begin{array}{l}37,138^{\mathrm{A}} \\
(91,536)\end{array}$ & $\begin{array}{l}37,591^{\mathrm{A}} \\
(79,939)\end{array}$ & $\begin{array}{l}172,584^{\mathrm{B}} \\
(370,213)\end{array}$ & $\begin{array}{l}86,174^{\mathrm{A}} \\
(177,562)\end{array}$ \\
\hline Total property value* & $\begin{array}{l}148,028^{\mathrm{A}} \\
(572,859)\end{array}$ & $\begin{array}{l}52,492^{\mathrm{AB}} \\
(147,573)\end{array}$ & $\begin{array}{l}60,091^{\mathrm{AB}} \\
(115,348) \\
\end{array}$ & $\begin{array}{l}531,494^{\mathrm{B}} \\
(4,419,035) \\
\end{array}$ & $\begin{array}{l}189,318^{\mathrm{AB}} \\
(925,298)\end{array}$ \\
\hline Mortgage debt & $\begin{array}{l}179,211 \\
(278,524) \\
\end{array}$ & $\begin{array}{l}182,593 \\
(81,950) \\
\end{array}$ & $\begin{array}{l}159,018 \\
(121,406) \\
\end{array}$ & $\begin{array}{l}241,483 \\
(255,484)\end{array}$ & $\begin{array}{l}221,413 \\
(262,968) \\
\end{array}$ \\
\hline $\begin{array}{l}\text { Debts (other than } \\
\text { mortgage) }\end{array}$ & $\begin{array}{l}42,278 \\
(443,414) \\
\end{array}$ & $\begin{array}{l}3764 \\
(21,084)\end{array}$ & $\begin{array}{l}4552 \\
(19,947) \\
\end{array}$ & $\begin{array}{l}239,102 \\
(2,832,475)\end{array}$ & $\begin{array}{l}80,326 \\
(641,198)\end{array}$ \\
\hline
\end{tabular}

Significant difference between offenders involved in different types of organized crime are indicated per variable $(\dagger \mathrm{p}<0.10, * \mathrm{p}<.05, * * \mathrm{p}<0.01, * * * \mathrm{p}<.001)$. Within each row, different superscripts indicate a significant difference between offenders involved in different types of organized crime ( $<<0.05)$. For example, $A$ and $B$ differ significantly; $A B$ differs from neither $A$ nor $B$ 
Table 9 Effect of employment on crime differentiated by type of organized crime

\begin{tabular}{|c|c|c|c|c|c|}
\hline & $\begin{array}{l}\text { Model } 6 \\
\text { Drugs }\end{array}$ & $\begin{array}{l}\text { Model } 7 \\
\text { Human } \\
\text { smuggling }\end{array}$ & $\begin{array}{l}\text { Model } 8 \\
\text { Human } \\
\text { trafficking }\end{array}$ & $\begin{array}{l}\text { Model } 9 \\
\text { Fraud }\end{array}$ & $\begin{array}{l}\text { Model } 10 \\
\text { Other offence }\end{array}$ \\
\hline & \multicolumn{5}{|l|}{$\mathrm{B}(\mathrm{SD})$} \\
\hline \multicolumn{6}{|c|}{ Control variables } \\
\hline Age & $.04 * *(.01)$ & $.03(.05)$ & $.04(.05)$ & $.12 * * *(.02)$ & $.08 * * *(.02)$ \\
\hline $\mathrm{Age}^{2}$ & $-.00 * * *(.00)$ & $-.00 * *(.00)$ & $-.00 * *(.00)$ & $-.00 * * *(.00)$ & $-.00 * * *(.00)$ \\
\hline \multicolumn{6}{|l|}{ Employment } \\
\hline $\begin{array}{l}\text { Employed } \\
\text { (for at least } \\
\text { a half year) }\end{array}$ & $-0.00(.04)$ & $-.20(.18)$ & $.02(.18)$ & $-.02(.07)$ & $-.10(.09)$ \\
\hline $\begin{array}{l}\text { Log } \\
\text { likelihood }\end{array}$ & $-10,231.07$ & -687.37 & -512.77 & -3027.56 & -2050.00 \\
\hline
\end{tabular}

$\dagger \mathrm{p}<0.10, * \mathrm{p}<.05, * * \mathrm{p}<0.01, * * * \mathrm{p}<.001$

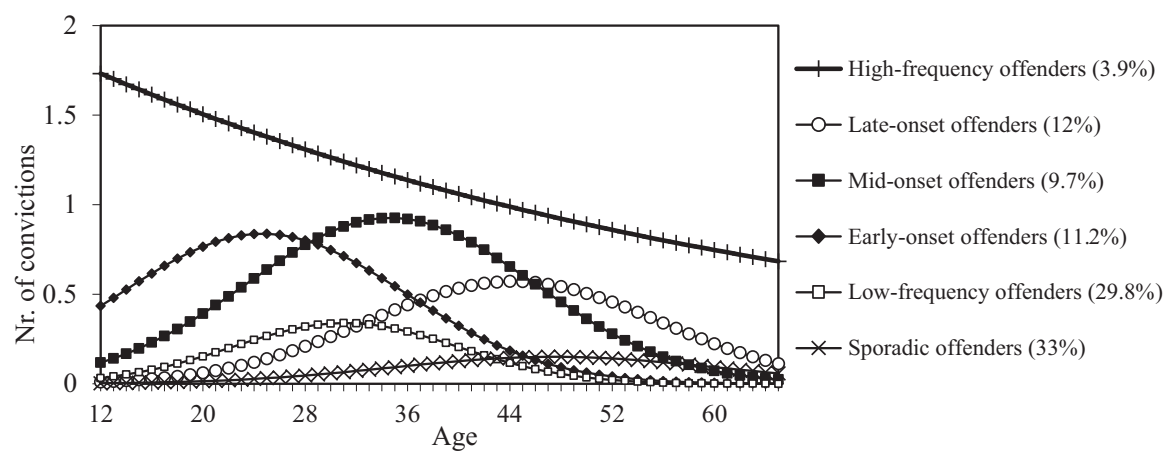

Fig. 3 Developmental trajectories of offending from age 12 to 65

assigned to a trajectory group named sporadic offenders. At age 37, individuals assigned to this group had the latest onset age of all groups. One out of four sporadic offenders had no other judicial contacts than the criterion case in organized crime and only $1 \%$ committed more than 10 crimes in total. As we would expect from their low-frequency offending trajectory, sporadic offenders committed significantly less crimes ( 3 in total) and less often spent time in prison (56\%) compared to all other offender groups.

Offenders assigned to trajectories with a lower offence frequency, seem to do better on employment outcomes. Low-frequency offenders and sporadic offenders, for example, are most often employed 7 years or more during the observation period, on average have higher numbers of employed days per year during the observation period, and also have higher incomes than individuals in most of the other trajectory groups (Table 11). High-frequency offenders have the lowest employment outcomes, together with the early- and mid-onset offenders; they are less often employed, have lower incomes, and more often received social benefits. No effect for employment on crime was found for any of the trajectory groups (Table 12). 
Table 10 Offending distinguished by trajectory group

\begin{tabular}{l|l|l|l|l|l|l}
\hline & $\begin{array}{l}\text { Early- } \\
\text { onset } \\
\text { offenders } \\
(\mathrm{N}=215)\end{array}$ & $\begin{array}{l}\text { Mid-onset } \\
\text { offenders } \\
(\mathrm{N}=186)\end{array}$ & $\begin{array}{l}\text { Late-onset } \\
\text { offenders } \\
(\mathrm{N}=232)\end{array}$ & $\begin{array}{l}\text { Low- } \\
\text { frequency } \\
\text { offenders } \\
(\mathrm{N}=573)\end{array}$ & $\begin{array}{l}\text { High- } \\
\text { frequency } \\
\text { offenders } \\
(\mathrm{N}=75)\end{array}$ & $\begin{array}{l}\text { Sporadic } \\
\text { offenders } \\
(\mathrm{N}=640)\end{array}$ \\
\hline & Mean $(\mathrm{SD}) / \mathrm{N}(\%)$ & & \\
\hline $\begin{array}{l}\text { Age at first } \\
\text { crime } * * *\end{array}$ & $16.7^{\mathrm{A}}(2.7)$ & $19.6^{\mathrm{B}}(3.6)$ & $28.1^{\mathrm{C}}(6.3)$ & $22.3^{\mathrm{D}}(4.7)$ & $\begin{array}{l}16.4^{\mathrm{A}} \\
(3.6)\end{array}$ & $36.8^{\mathrm{E}}(9.9)$ \\
\hline $\begin{array}{l}\text { Age at criterion } \\
\text { case } * * *\end{array}$ & $32.3^{\mathrm{A}}(6.7)$ & $37.3^{\mathrm{B}}(7.7)$ & $44.7^{\mathrm{C}}(8.1)$ & $32.7^{\mathrm{A}}(6.9)$ & $\begin{array}{l}36.8^{\mathrm{B}} \\
(8.0)\end{array}$ & $\begin{array}{l}42.5^{\mathrm{C}} \\
(10.7)\end{array}$ \\
\hline
\end{tabular}

\section{Total criminal career}

\begin{tabular}{|c|c|c|c|c|c|c|}
\hline $\begin{array}{l}\text { One-shot } \\
\text { offender } * * *\end{array}$ & $0(0 \%)$ & $0(0 \%)$ & $0(0 \%)$ & $7(1 \%)$ & $0(0 \%)$ & $165(26 \%)$ \\
\hline $2-5$ crimes $* * *$ & $1(1 \%)$ & $1(1 \%)$ & $3(1 \%)$ & $233(41 \%)$ & $0(0 \%)$ & $355(56 \%)$ \\
\hline 6-10 crimes $* * *$ & $19(9 \%)$ & $14(8 \%)$ & $57(25 \%)$ & $258(45 \%)$ & $0(0 \%)$ & $108(17 \%)$ \\
\hline$>10$ crimes $* * *$ & $195(91 \%)$ & $171(92 \%)$ & $172(74 \%)$ & $75(13 \%)$ & $75(100 \%)$ & $4(1 \%)$ \\
\hline $\begin{array}{l}\text { Number of } \\
\text { crimes } * * *\end{array}$ & $19.3^{\mathrm{A}}(6.9)$ & $21.6^{\mathrm{B}}(7.8)$ & $14.3^{\mathrm{C}}(5.9)$ & $6.7^{\mathrm{D}}(3.2)$ & $\begin{array}{l}47.3^{\mathrm{E}} \\
(16.7)\end{array}$ & $3.2^{\mathrm{B}}(2.3)$ \\
\hline Violence $* * *$ & $2.2^{\mathrm{A}}(2.1)$ & $2.1^{\mathrm{A}}(2.2)$ & $1.1^{\mathrm{B}}(1.5)$ & $0.5^{\mathrm{C}}(0.8)$ & $5.4^{\mathrm{C}}(4.6)$ & $0.2^{\mathrm{D}}(0.5)$ \\
\hline Property $* * *$ & $4.6^{\mathrm{A}}(4.1)$ & $3.6^{\mathrm{B}}(3.4)$ & $1.9^{\mathrm{C}}(2.2)$ & $1.0^{\mathrm{D}}(1.2)$ & $\begin{array}{l}16.2^{\mathrm{E}} \\
(11.3)\end{array}$ & $0.6^{\mathrm{D}}(0.8)$ \\
\hline Drugs**** & $1.2^{\mathrm{A}}(1.4)$ & $1.5^{\mathrm{AB}}(2.0)$ & $1.3^{\mathrm{A}}(1.4)$ & $0.7^{\mathrm{C}}(0.9)$ & $1.8^{\mathrm{B}}(1.9)$ & $0.4^{\mathrm{D}}(0.7)$ \\
\hline Other*** & $11.2^{\mathrm{A}}(5.4)$ & $14.4^{\mathrm{B}}(6.0)$ & $10.0^{\mathrm{A}}(5.1)$ & $4.6^{\mathrm{C}}(2.7)$ & $\begin{array}{l}23.9^{\mathrm{D}} \\
(12.3)\end{array}$ & $2.0^{\mathrm{E}}(2.0)$ \\
\hline $\begin{array}{l}\text { Number of minor } \\
\text { crimes }(<4 \text { years } \\
\text { punishment } \\
\text { threat)*** }\end{array}$ & $10.4^{\mathrm{A}}(5.5)$ & $13.7^{\mathrm{B}}(5.8)$ & $9.7^{\mathrm{A}}(5.0)$ & $4.2^{\mathrm{C}}(2.7)$ & $\begin{array}{l}21.9^{\mathrm{D}} \\
(11.8)\end{array}$ & $1.8^{\mathrm{E}}(1.9)$ \\
\hline $\begin{array}{l}\text { Number of } \\
\text { moderate crimes } \\
\text { ( } 4-8 \text { years } \\
\text { punishment } \\
\text { threat)*** }\end{array}$ & $7.3^{\mathrm{A}}(5.0)$ & $6.4^{\mathrm{A}}(4.6)$ & $3.7^{\mathrm{B}}(2.9)$ & $1.8^{\mathrm{C}}(1.6)$ & $\begin{array}{l}22.4^{\mathrm{D}} \\
(11.6)\end{array}$ & $1.0^{\mathrm{E}}(1.0)$ \\
\hline $\begin{array}{l}\text { Number of serious } \\
\text { crimes ( }>=8 \text { years } \\
\text { punishment } \\
\text { threat)*** }\end{array}$ & $1.6^{\mathrm{A}}(1.6)$ & $1.5^{\mathrm{A}}(1.5)$ & $1.0^{\mathrm{B}}(1.1)$ & $0.6^{\mathrm{C}}(0.8)$ & $3.1^{\mathrm{D}}(2.4)$ & $0.5^{\mathrm{E}}(0.6)$ \\
\hline $\begin{array}{l}\text { At least one prison } \\
\text { sentence } * * *\end{array}$ & $203(94 \%)$ & $166(89 \%)$ & $200(86 \%)$ & $425(74 \%)$ & $75(100 \%)$ & $361(56 \%)$ \\
\hline $\begin{array}{l}\text { Number of prison } \\
\text { sentences } * * *\end{array}$ & $4.7^{\mathrm{A}}(3.1)$ & $4.6^{\mathrm{A}}(3.8)$ & $2.8^{\mathrm{B}}(2.6)$ & $1.4^{\mathrm{C}}(1.4)$ & $\begin{array}{l}14.5^{\mathrm{D}} \\
(7.2) \\
\end{array}$ & $0.8^{\mathrm{E}}(0.9)$ \\
\hline $\begin{array}{l}\text { Time spent in } \\
\text { prison (years) } * * *\end{array}$ & $3.6^{\mathrm{A}}(4.2)$ & $3.9^{\mathrm{A}}(5.2)$ & $2.9^{\mathrm{A}}(4.1)$ & $1.8^{\mathrm{B}}(2.8)$ & $6.8^{\mathrm{C}}(5.8)$ & $1.1^{\mathrm{D}}(2.4)$ \\
\hline \multicolumn{7}{|l|}{ Organized crime case } \\
\hline Prison sentence & $77(36 \%)$ & $68(37 \%)$ & $89(38 \%)$ & $224(39 \%)$ & $28(37 \%)$ & $219(34 \%)$ \\
\hline $\begin{array}{l}\text { Length of prison } \\
\text { sentence (years)* }\end{array}$ & $1.0^{\mathrm{A}}(1.8)$ & $0.9^{\mathrm{A}}(1.9)$ & $1.0^{\mathrm{A}}(1.9)$ & $0.9^{\mathrm{A}}(1.7)$ & $1.1^{\mathrm{A}}(2.0)$ & $0.7^{\mathrm{A}}(1.6)$ \\
\hline
\end{tabular}

Significant difference between the trajectory groups are indicated per variable $(\dagger \mathrm{p}<0.10, * \mathrm{p}<.05$, $* * \mathrm{p}<0.01, * * * \mathrm{p}<.001)$. Within each row, different superscripts indicate a significant difference between trajectory groups ( $\mathrm{p}<0.05$ ). For example, $A$ and $B$ differ significantly; $A B$ differs from neither $A$ nor $B$. Link between offending trajectory and employment 
Table 11 Life outcomes distinguished by trajectory group

\begin{tabular}{|c|c|c|c|c|c|c|}
\hline & $\begin{array}{l}\text { Early- } \\
\text { onset } \\
\text { offenders } \\
(\mathrm{N}=215)\end{array}$ & $\begin{array}{l}\text { Mid-onset } \\
\text { offenders } \\
(\mathrm{N}=186)\end{array}$ & $\begin{array}{l}\text { Late-onset } \\
\text { offenders } \\
(\mathrm{N}=232)\end{array}$ & $\begin{array}{l}\text { Low- } \\
\text { frequency } \\
\text { offenders } \\
(\mathrm{N}=573)\end{array}$ & $\begin{array}{l}\text { High- } \\
\text { frequency } \\
\text { offenders } \\
(\mathrm{N}=75)\end{array}$ & $\begin{array}{l}\text { Sporadic } \\
\text { offenders } \\
(\mathrm{N}=640)\end{array}$ \\
\hline & \multicolumn{6}{|c|}{ Mean (SD) / N (\%) } \\
\hline \multicolumn{7}{|c|}{ Highest educational level $* * *$} \\
\hline $\begin{array}{l}\text { Elementary } \\
\text { education }\end{array}$ & $40(19 \%)$ & $39(21 \%)$ & $29(13 \%)$ & $73(13 \%)$ & $22(29 \%)$ & $75(12 \%)$ \\
\hline $\begin{array}{l}\text { Prevocational } \\
\text { education }\end{array}$ & $22(10 \%)$ & $25(13 \%)$ & $19(8 \%)$ & $85(15 \%)$ & $12(16 \%)$ & $42(7 \%)$ \\
\hline $\begin{array}{l}\text { Selective } \\
\text { secondary } \\
\text { education }\end{array}$ & $<10$ & $<10$ & $<10$ & $<10$ & $<10$ & $<10$ \\
\hline $\begin{array}{l}\text { Vocational } \\
\text { training }\end{array}$ & $30(14 \%)$ & $17(9 \%)$ & $20(9 \%)$ & $84(15 \%)$ & $10(13 \%)$ & $75(12 \%)$ \\
\hline Higher education & $12(6 \%)$ & $11(6 \%)$ & $15(6 \%)$ & $51(9 \%)$ & $<10$ & $68(11 \%)$ \\
\hline Unknown & $111(52 \%)$ & $94(51 \%)$ & $149(64 \%)$ & $280(49 \%)$ & $30(40 \%)$ & $380(59 \%)$ \\
\hline \multicolumn{7}{|l|}{ Employed $* * *$} \\
\hline $\begin{array}{l}\text { Never during } \\
\text { observation period }\end{array}$ & $42(20 \%)$ & $48(26 \%)$ & $77(33 \%)$ & $106(19 \%)$ & $18(24 \%)$ & $176(28 \%)$ \\
\hline $0-0.5$ year & $26(12 \%)$ & $24(13 \%)$ & $23(10 \%)$ & $37(6 \%)$ & $22(29 \%)$ & $36(6 \%)$ \\
\hline $0.5-3.0$ years & $53(25 \%)$ & $59(32 \%)$ & $50(22 \%)$ & $108(19 \%)$ & $20(27 \%)$ & $125(20 \%)$ \\
\hline $3.0-7.0$ years & $50(23 \%)$ & $40(22 \%)$ & $42(18 \%)$ & $127(22 \%)$ & $11(15 \%)$ & $112(18 \%)$ \\
\hline$>7$ years & $44(21 \%)$ & $25(13 \%)$ & $47(20 \%)$ & $195(34 \%)$ & $4(5 \%)$ & $201(31 \%)$ \\
\hline $\begin{array}{l}\lambda \text { (mean number } \\
\text { of employed days } \\
\text { during the } \\
\text { observation } \\
\text { period)*** }\end{array}$ & $\begin{array}{l}77.0^{\mathrm{A}} \\
(84.5)\end{array}$ & $\begin{array}{l}60.5^{\mathrm{AB}} \\
(77.1)\end{array}$ & $\begin{array}{l}70.5^{\mathrm{AB}} \\
(95.0)\end{array}$ & $\begin{array}{l}113.9^{\mathrm{C}} \\
(110.4)\end{array}$ & $\begin{array}{l}35.3^{\mathrm{B}} \\
(53.5)\end{array}$ & $\begin{array}{l}105.2^{\mathrm{C}} \\
(115.4)\end{array}$ \\
\hline $\begin{array}{l}\text { Ever self- } \\
\text { employed during } \\
\text { observation } \\
\text { period } \dagger\end{array}$ & $55(26 \%)$ & $62(33 \%)$ & $80(35 \%)$ & $147(26 \%)$ & $17(23 \%)$ & $175(27 \%)$ \\
\hline $\begin{array}{l}\text { Mean income per } \\
\text { observed year (in } \\
\text { euros)*** }\end{array}$ & $\begin{array}{l}11,349 \\
(13,048)^{\mathrm{A}}\end{array}$ & $\begin{array}{l}13,503 \\
(17,946)^{A B}\end{array}$ & $\begin{array}{l}18,722 \\
(23,424)^{\mathrm{BC}}\end{array}$ & $\begin{array}{l}18,271 \\
(19,987)^{\text {в }}\end{array}$ & $\begin{array}{l}9907 \\
(7959)^{\mathrm{A}}\end{array}$ & $\begin{array}{l}23,576 \\
(27,317)^{\mathrm{C}}\end{array}$ \\
\hline $\begin{array}{l}\text { Mean income } \\
\text { percentile per } \\
\text { observed year } * * *\end{array}$ & $\begin{array}{l}31.3 \\
(19.8)^{\mathrm{A}}\end{array}$ & $\begin{array}{l}33.6 \\
(21.2)^{\mathrm{AB}}\end{array}$ & $\begin{array}{l}38.8 \\
(23.5)^{\mathrm{BC}}\end{array}$ & $\begin{array}{l}40.3 \\
(23.7)^{\mathrm{C}}\end{array}$ & $\begin{array}{l}27.0 \\
(15.2)^{\mathrm{AB}}\end{array}$ & $44.6(24.9)^{\mathrm{D}}$ \\
\hline $\begin{array}{l}\text { Proportion of } \\
\text { observed years } \\
\text { with positive } \\
\text { income } * * *\end{array}$ & $0.6(0.3)^{\mathrm{A}}$ & $0.7(0.3)^{\mathrm{AB}}$ & $0.7(0.3)^{\mathrm{BC}}$ & $0.7(0.3)^{\mathrm{C}}$ & $0.7(0.3)^{A C}$ & $0.8(0.3)^{\mathrm{D}}$ \\
\hline $\begin{array}{l}\text { Ever received } \\
\text { social benefits } \\
\text { during } \\
\text { observation } \\
\text { period } * * *\end{array}$ & $83(40 \%)$ & $75(41 \%)$ & $59(26 \%)$ & $196(37 \%)$ & $43(57 \%)$ & $68(28 \%)$ \\
\hline
\end{tabular}


Table 11 (continued)

\begin{tabular}{|c|c|c|c|c|c|c|}
\hline & $\begin{array}{l}\text { Early- } \\
\text { onset } \\
\text { offenders } \\
(\mathrm{N}=215)\end{array}$ & $\begin{array}{l}\text { Mid-onset } \\
\text { offenders } \\
(\mathrm{N}=186)\end{array}$ & $\begin{array}{l}\text { Late-onset } \\
\text { offenders } \\
(\mathrm{N}=232)\end{array}$ & $\begin{array}{l}\text { Low- } \\
\text { frequency } \\
\text { offenders } \\
(\mathrm{N}=573)\end{array}$ & $\begin{array}{l}\text { High- } \\
\text { frequency } \\
\text { offenders } \\
(\mathrm{N}=75)\end{array}$ & $\begin{array}{l}\text { Sporadic } \\
\text { offenders } \\
(\mathrm{N}=640)\end{array}$ \\
\hline & \multicolumn{6}{|c|}{ Mean (SD) / N (\%) } \\
\hline $\begin{array}{l}\text { Main property } \\
\text { value*** }\end{array}$ & $\begin{array}{l}49,961^{\mathrm{A}} \\
(127,912)\end{array}$ & $\begin{array}{l}67,137^{\mathrm{A}} \\
(128390)\end{array}$ & $\begin{array}{l}110,671^{\mathrm{AB}} \\
(232,233)\end{array}$ & $\begin{array}{l}75,344^{\mathrm{A}} \\
(170,029)\end{array}$ & $\begin{array}{l}17,308^{\mathrm{A}} \\
(62,634)\end{array}$ & $\begin{array}{l}141,341^{\mathrm{B}} \\
(311,585)\end{array}$ \\
\hline $\begin{array}{l}\text { Total property } \\
\text { value }\end{array}$ & $\begin{array}{l}173,493 \\
(986,225)\end{array}$ & $\begin{array}{l}151,485 \\
(571,628)\end{array}$ & $\begin{array}{l}248,003 \\
(986,861)\end{array}$ & $\begin{array}{l}109,140 \\
(315,236)\end{array}$ & $\begin{array}{l}57,805 \\
(312,941)\end{array}$ & $\begin{array}{l}377,778 \\
(3,484,204)\end{array}$ \\
\hline Mortgage debt $\dagger$ & $\begin{array}{l}160,232 \\
(158,204)\end{array}$ & $\begin{array}{l}134,947 \\
(122,165)\end{array}$ & $\begin{array}{l}252,657 \\
(539,334)\end{array}$ & $\begin{array}{l}183,121 \\
(169,941)\end{array}$ & $\begin{array}{l}92,110 \\
(103,100)\end{array}$ & $\begin{array}{l}223,635 \\
(231,597)\end{array}$ \\
\hline $\begin{array}{l}\text { Debts (other than } \\
\text { mortgage) }\end{array}$ & $\begin{array}{l}75,045 \\
(625,224)\end{array}$ & $\begin{array}{l}29,118 \\
(202,548)\end{array}$ & $\begin{array}{l}108,909 \\
(895,649)\end{array}$ & $\begin{array}{l}20,339 \\
(180,173)\end{array}$ & $\begin{array}{l}21,023 \\
(167,805)\end{array}$ & $\begin{array}{l}155,551 \\
(2,235,473)\end{array}$ \\
\hline
\end{tabular}

Significant difference between trajectory groups are indicated per variable $(\dagger \mathrm{p}<0.10, * \mathrm{p}<.05$, $* * \mathrm{p}<0.01, * * * \mathrm{p}<.001)$. Within each row, different superscripts indicate a significant difference between trajectory groups $(\mathrm{p}<0.05)$. For example, $A$ and $B$ differ significantly; $A B$ differs from neither $A$ nor $B$

Table 12 Effect of employment on crime differentiated by trajectory group

\begin{tabular}{|c|c|c|c|c|c|c|}
\hline & $\begin{array}{l}\text { Model } 11 \\
\text { Early-onset } \\
\text { offenders }\end{array}$ & $\begin{array}{l}\text { Model } 12 \\
\text { Mid-onset } \\
\text { offenders }\end{array}$ & $\begin{array}{l}\text { Model } 13 \\
\text { Late-onset } \\
\text { offenders }\end{array}$ & $\begin{array}{l}\text { Model } 14 \\
\text { Low- } \\
\text { frequency } \\
\text { offenders }\end{array}$ & $\begin{array}{l}\text { Model } 15 \\
\text { High- } \\
\text { frequency } \\
\text { offenders }\end{array}$ & $\begin{array}{l}\text { Model } 16 \\
\text { Sporadic } \\
\text { offenders }\end{array}$ \\
\hline & \multicolumn{6}{|l|}{ B (SD) } \\
\hline \multicolumn{7}{|c|}{ Control variables } \\
\hline Age & $\begin{array}{l}.26 * * * \\
(.03)\end{array}$ & $.05 *(.02)$ & $\begin{array}{l}.19 * * * \\
(.02)\end{array}$ & $.21 * * *(.03)$ & $.07 * *(.02)$ & $\begin{array}{l}.13 * * * \\
(.03)\end{array}$ \\
\hline $\mathrm{Age}^{2}$ & $\begin{array}{l}-.01 * * * \\
(.00)\end{array}$ & $\begin{array}{l}-.00 * * * \\
(.00)\end{array}$ & $\begin{array}{l}-.00 * * * \\
(.00)\end{array}$ & $\begin{array}{l}-.00 * * * \\
(.00)\end{array}$ & $-.00 * * *(.00)$ & $\begin{array}{l}-.00 * * * \\
(.00)\end{array}$ \\
\hline \multicolumn{7}{|l|}{ Employment } \\
\hline $\begin{array}{l}\text { Employed } \\
\text { (for at least a } \\
\text { half year) }\end{array}$ & $.02(.06)$ & $.02(.07)$ & $-.00(.07)$ & $-.10(.08)$ & $-.05(.10)$ & $-.01(.09)$ \\
\hline $\begin{array}{l}\text { Log } \\
\text { likelihood }\end{array}$ & -3713.70 & -2549.63 & -2805.67 & -2786.22 & -1728.77 & -2745.58 \\
\hline
\end{tabular}

$\dagger \mathrm{p}<0.10, * \mathrm{p}<.05, * * \mathrm{p}<0.01, * * * \mathrm{p}<.001$

\section{Discussion}

This chapter focused on the criminal careers of 1921 offenders from the Dutch Organized Crime Monitor and analyzed delinquent development and relationships with socio-economic variables such as employment and income. Next to many detailed findings for various subgroups on the criterion case, development of offending, educational level, employment and income, the most important conclusions are the following. First, organized crime offenders, on average were 27 years 
old when their first judicial contact took place and, compared to the traditional age-crime curve (e.g. Gottfredson and Hirschi 1990), offending stayed relatively high and only started dropping to a lower level from age $50 \mathrm{on}$. This is similar to findings in previous studies on Dutch organized crime offenders, in which age of onset ranges between 24-27 (Kleemans and De Poot 2008; Van Koppen et al. 2010a. Also Savona et al. (2020), find that mafia members committed their first crime at on average age 25 . Their analysis of trajectories reveals roughly similar patterns, with a small group of persistent high-frequency offenders. In studies in the UK and Australia, organized crime offenders are slightly younger at their first offence, but this is also true for general offenders (Francis et al. 2013; Fuller et al. 2019). Second, no effect was found of employment on crime for the total sample. This finding is markedly different from earlier studies on general offender samples, that identified an effect of employment on crime (Van der Geest et al. 2011; Laub and Sampson 2003). Studies on white-collar crime offenders, however, show that employment can also provide specific opportunities that lead offenders into crime (Weisburd et al. 2001; Van Onna 2018). Similarly, in organized crime certain occupations may present opportunities for committing crimes, for example through travel movements or international contacts, and depending on the nature of the occupation, the effect of employment on crime may be differential. Third, interesting findings emerged from analyses where individuals were distinguished based on their role in a criminal organization. Both leaders and coordinators show a different pattern than is standard in the literature on the relationship between employment and crime: both for leaders and coordinators, a significant positive effect of employment on crime was found. Employment significantly increases offending with $31 \%$ for leaders and with $46 \%$ for coordinators. The only group that benefits from employment, are those with other roles; employment accounts for a crime reduction of $7 \%$ for this subgroup. Fourth, no effect was found of employment on crime for subgroups distinguished by type of organized crime activity. Fifth, trajectory analyses resulted in the selection of a model with six groups: high-frequency offenders $(3.9 \%)$, early-onset offenders $(11.2 \%)$, mid-onset offenders $(9.7 \%)$, lateonset offenders (12\%), low-frequency offenders $(29.8 \%)$, and sporadic offenders (33\%). Sixth, offenders assigned to trajectories with a lower offence frequency, seem to do better on employment outcomes. No effect for employment on crime was found for any of the trajectory groups. This study describing long-term criminal career characteristics and differential effects of employment on crime in a sample of organized crime offenders, has added new findings to literature on work and crime. Work settings may provide new opportunities for organized crime activities, as is demonstrated by qualitative research (e.g. Kleemans and Van de Bunt 2008; Madarie and Kruisbergen 2020). Therefore, the received wisdom that employment has a preventive effect on crime does not seem to hold for careers in organized crime. An interesting finding is that the effect of employment may differ for different roles in criminal organizations. Both for leaders and coordinators, we found that employment actually increases offending, whereas for other roles employment led to a (small) reduction in crime. Testing to what extent the effect also differs by the type of occupation was beyond the scope of this chapter, and 
also the role of self-employment in organized crime remains largely unknown. These findings call for more research on the link between employment and organized crime.

Acknowledgements The data used in this chapter are part of a continuing research project, the Dutch Organized Crime Monitor, combined with information from the Dutch Judicial Documentation System and Statistics Netherlands. We are grateful to all past and present members of the Dutch Organized Crime Monitor research group for their efforts and particularly to Edwin Kruisbergen for his contribution to this specific study. We also thank the members of the Recidivism Monitor team of the Research and Documentation Centre and our contact persons at Statistics Netherlands for their data deliveries and helpful support to this study.

\section{Bayesian Information Criterion Values per Model}

\begin{tabular}{l|l}
\hline Number of groups & $\begin{array}{l}\text { Bayesian Information } \\
\text { Criterion }\end{array}$ \\
\hline 1 & $-49,603.19$ \\
\hline 2 & $-46,259.48$ \\
\hline 3 & $-45,667.88$ \\
\hline 4 & $-45,197.78$ \\
\hline 5 & $-44,952.59$ \\
\hline 6 & $-44,834.29$ \\
\hline 7 & $-44,848.75$ \\
\hline
\end{tabular}

Zero-Inflated Poisson quadratic model with six groups

\begin{tabular}{|c|c|c|c|c|c|c|}
\hline \multirow[b]{2}{*}{ Variable } & \multicolumn{6}{|l|}{ Group } \\
\hline & $\begin{array}{l}\text { Early-onset } \\
\text { Offenders }\end{array}$ & $\begin{array}{l}\text { Mid-onset } \\
\text { Offenders }\end{array}$ & $\begin{array}{l}\text { Late-onset } \\
\text { Offenders }\end{array}$ & $\begin{array}{l}\text { Low- } \\
\text { frequency } \\
\text { Offenders }\end{array}$ & $\begin{array}{l}\text { High- } \\
\text { frequency } \\
\text { Offenders }\end{array}$ & $\begin{array}{l}\text { Sporadic } \\
\text { Offenders }\end{array}$ \\
\hline$n$ & 215 & 186 & 232 & 573 & 75 & 640 \\
\hline \multicolumn{7}{|c|}{ Estimated model parameters } \\
\hline Intercept & $-2.19 *$ & $-4.49 *$ & $-7.53 *$ & $-6.77 *$ & $1.21 *$ & $-8.06 *$ \\
\hline Linear & $2.01 *$ & $2.77 *$ & $3.36 *$ & $4.01 *$ & $-.18 *$ & $2.96 *$ \\
\hline Quadratic & $-.41 *$ & $-.40 *$ & $-.38 *$ & $-.64 *$ & - & $-.31 *$ \\
\hline \multicolumn{7}{|c|}{ Model characteristics ${ }^{\mathrm{a}}$} \\
\hline $\begin{array}{l}\text { Mean group } \\
\text { probabilities }\end{array}$ & .84 & .81 & .83 & .78 & .91 & .86 \\
\hline $\begin{array}{l}\text { Inflation } \\
\text { parameter }(\alpha)\end{array}$ & $-.53 *$ & $-.75 *$ & $-.52 *$ & $-.32 *$ & $-.57 *$ & $.32 *$ \\
\hline
\end{tabular}

${ }^{*} p<.05$

${ }^{a}$ Based on a six-group model 


\section{References}

Blokland, A., \& Van der Geest, V. (2017). International handbook of criminal careers and lifecourse criminology. London: Routledge.

Farrington, D. P. (2003). Developmental and life-course criminology: Key theoretical and empirical studies - The 2002 Sutherland award address. Criminology, 41, 221-255.

Fijnaut, C., Bovenkerk, F., Bruinsma, G., \& Van de Bunt, H. (1998). Organised crime in the Netherlands. The Hague: Kluwer Law International.

Francis, B., Humphreys, L., Kirby, S., \& Soothill, K. (2013). Understanding criminal careers in organised crime. Research Report, 74, Department of mathematics and statistics and department of applied social science, Lancaster University.

Fuller, G., Morgan, A., \& Brown, N. (2019). Criminal histories of Australian organised crime offenders. Trends and Issues in Crime and Criminal Justice, 567, 1-6.

Gottfredson, M. R., \& Hirschi, T. (1990). A general theory of crime. Stanford: Stanford University Press.

Kleemans, E. R. (2007). Organized crime, transit crime, and racketeering. Crime and Justice: A Review of Research, 35, 163-215.

Kleemans, E. R. (2014). Organized crime research: Challenging assumptions and informing policy. In E. Cockbain \& J. Knutsson (Eds.), Applied police research: Challenges and opportunities (pp. 57-67). London: Routledge.

Kleemans, E. R., \& De Poot, C. J. (2008). Criminal careers in organized crime and social opportunity structure. European Journal of Criminology, 5(1), 69-98.

Kleemans, E. R., \& Van de Bunt, H. G. (2008). Organised crime, occupations, and opportunity. Global Crime, 9(3), 185-197.

Laub, J., \& Sampson, R. (2003). Shared beginnings, divergent lives: Delinquent boys to age 70. Cambridge, MA: Harvard University Press.

Madarie, R., \& Kruisbergen, E. W. (2020). Traffickers in Transit: Analysing the logistics and involvement mechanisms of organized crime at logistical nodes in the Netherlands: Empirical results of the Dutch Organised Crime Monitor. In D. Weisburd, E. U. Savona, B. Hasisi, \& F. Calderoni (Eds.), Understanding Recruitment to Organized Crime and Terrorism. Cham: Springer International Publishing.

Nagin, D. S. (2005). Group-Based Modeling of Development. Cambridge, MA: Harvard University Press.

Nagin, D. S., Farrington, D. P., \& Moffitt, T. E. (1995). Life-course trajectories of different types of offenders. Criminology, 33, 111-139.

Reuter, P. (1983). Disorganized crime: Illegal markets and the mafia. Cambridge, MA: MIT Press.

Savona, E. U., Calderoni, F., Campedelli, G. M., Comunale, T., Ferrarini, M., \& Meneghini, C. (2020). The criminal careers of Italian mafia members. In D. Weisburd, E. U. Savona, B. Hasisi, \& F. Calderoni (Eds.), Understanding Recruitment to Organized Crime and Terrorism. Cham: Springer International Publishing.

Statistics Netherlands. (August 13, 2018). Statline. https://opendata.cbs.nl/statline/\#/CBS/nl/

Van der Geest, V. R. (2011). Working their way into adulthood: Delinquency and employment in high-risk boys to age 32. Doctorate thesis.

Van der Geest, V. R., Bijleveld, C. C. J. H., \& Blokland, A. A. J. (2011). The effects of employment on longitudinal trajectories of offending: A follow-up in high risk youth from ages 12 to 32 . Criminology, 39(4), 1195-1234.

Van Onna, J. (2018). Blurred lines: A study of white-collar crime involvement. $\mathrm{PhD}$ thesis, VU University Amsterdam: Joost van Onna.

Van Koppen, M. V. (2013). Involvement mechanisms for organized crime. Crime, Law and Social Change, 59(1), 1-20. 
Van Koppen, M. V., De Poot, C. J., \& Blokland, A. A. J. (2010a). Comparing criminal careers of organized crime offenders and general offenders. European Journal of Criminology, 7(5), 356-374.

Van Koppen, M. V., De Poot, C. J., Kleemans, E. R., \& Nieuwbeerta, P. (2010b). Criminal trajectories in organized crime. The British Journal of Criminology, 50(1), 102-123.

Weisburd, D., Waring, E., \& Chayet, E. F. (2001). White-collar crime and criminal careers. Cambridge, UK: Cambridge University Press.

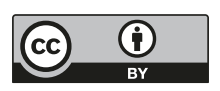

Open Access This chapter is licensed under the terms of the Creative Commons Attribution 4.0 International License (http://creativecommons.org/licenses/by/4.0/), which permits use, sharing, adaptation, distribution and reproduction in any medium or format, as long as you give appropriate credit to the original author(s) and the source, provide a link to the Creative Commons license and indicate if changes were made.

The images or other third party material in this chapter are included in the chapter's Creative Commons license, unless indicated otherwise in a credit line to the material. If material is not included in the chapter's Creative Commons license and your intended use is not permitted by statutory regulation or exceeds the permitted use, you will need to obtain permission directly from the copyright holder. 